\title{
28 Research Soure \\ Gender and Leg-dominance Differences in Shoe Properties and Foot Injuries in Badminton
}

\section{Siqin Shen ( $\nabla$ shensiqinnbu@gmail.com )}

Ningbo University

\section{Wing-Kai Lam}

Shenyang Sports College: Shenyang Sport University

\section{Jin Teng}

Beijing Sport University

\section{Sheng-Wei Jia}

Li Ning Sports science research center

Julien S. Baker

Ningbo University

Ukadike C. Ugbolue

Ningbo University

\section{Guszáv Fekete}

Eotvos Lorand University: Eotvos Lorand Tudomanyegyetem

\section{Yaodong Gu}

Ningbo University

\section{Research Article}

Keywords: Badminton shoes, questionnaire, gender, function, foot injuries

Posted Date: January 13th, 2022

DOI: https://doi.org/10.21203/rs.3.rs-1241312/v1

License: (c) (i) This work is licensed under a Creative Commons Attribution 4.0 International License.

Read Full License 


\section{Abstract}

Background: While the roles of injury prevention and performance enhancement have increasingly been investigated for badminton footwear, there is a lack of research on gender-specific badminton footwear. The purpose of this study was to examine the gender differences in footwear demands and foot injuries in badminton.

Methods: A supervised questionnaire survey of 326 recreational badminton players was collected. The questionnaire was divided into four sections enquiring about the characteristics of (1) participant profiles, (2) importance of shoe properties (3) shoe complaints. (4) and pain or discomfort in different foot regions. The Mann-Whitney U test and Wilcoxon Signed Ranks test were performed to determine the differences between genders and the differences between leg dominance, respectively. The significance level was set at 0.05 .

Results: Both males and females rated shoe fit as the most important features, followed by overall comfort, and injury protection. Females considered forefoot cushioning, comfort, breathability and color as the more important compared with other properties, which showed distinct pattern differences from males. The shoe problem results indicated that plantar pain of the non-dominant foot was considered the most commonly reported footwear problem by both males and females. The problem of excessive archsupport on the dominant and non-dominant sides of male participants was significantly higher than females $(p<05)$. Occasional pain or frequent pain were mainly distributed in the forefoot, followed by the rearfoot and midfoot regions.

Conclusion: There were small differences in footwear demand between the dominant and non-dominant sides, but several differences existed between females and males. The results from gender differences suggested that female specific shoes prefer a specific better fit, rather than a modified version of male shoes. In the future, the design of badminton shoes should consider footwear demands and foot discomfort profiles in respective male and female badminton players.

\section{Introduction}

Badminton is one of the most popular recreational sports worldwide. It requires athletes to maintain highintensity exercises and rapid changes of direction. In a badminton competition, athletes intermittently perform repetitive strenuous movements including rapid acceleration and turning, sidestepping, crossoverstepping, lunging, jumping, high clear and smash, which exert high strains on the lower extremities and functional characteristics in the sport, because they act as the interface between the foot and ground. It is known that modification of shoe construction (e.g., midsole material, heel cup height, heel to toe drop) can induce a kinematic and kinetics adaption, which influences sport performance and potential injury risks in various sports [1][2][3]For instance, better shoe cushioning is related to better impact attenuation [4-6]; increased shoe bending stiffness is related to improve jumping, sprint and 
agility performances $[5,6]$. Matching footwear requirements with movement characteristics is beneficial to improve footwear development.

Biomechanical research of badminton sneakers typically focus on kinematic [4] and kinetic [5] variables associated with performances injuries in badminton. Highspeed cameras and force platforms are usually used to quantify movement characteristics and joint loading. However, these would cost enormous financial and human resources. In contrast, retrospective studies in hospital clinics tend to underestimate the incidence and types of injuries [7] because injured amateur players often do not seek medical help, especially in the case of minor injuries (e.g., blisters, ankle sprain). Morever, retrospective studies employ personal interviews and structured questionnaires [8] can allow researchers to gather a vast amount of data using reasonable human and financial resources. In addition to performance and injury, Llana et al. [9] raised the issue of the comfort of sport shoes. These fundamentals can be used in the design and development process of athletic shoes to improve shoe quality and specific function.

Footwear structural features have the potential to affect comfort and athletic performances [10]. Sport shoe characteristics for running, gym, football, basketball, and tennis have been previously studied using questionnaires [1,11-14], but information for badminton has not been established. Movement mechanics and loading characteristics in badminton are clearly different from running and other court sports, resulting in distinct requirements of footwear. So far, there is a lack of study on gender-specific badminton shoes. Compared to males, a lower maximal stiffness and higher elasticity within the heel pad have been noted in females [15]. Additionally, young males have significantly increased midfoot fat pad thickness compared to young females[16]. Furthermore, a recent study by Tas and colleagues showed males have a significantly larger plantar fascia and heel fat pad thickness compared with females [17]. Several papers show that female feet were not just a scaled down version of male feet $[18,19]$ female feet were characterized by a higher arch, shallower first toe, shorter length of the outside ball and smaller instep circumference. Other etiological factors, including hip Q-angle, foot shape, body mass, muscle strength, and joint laxity, are different between genders [13], which results in distinct biomechanical alternations and thereby footwear requirements between male and females [11], when selecting badminton shoes.

The functional requirements of a shoe are multifaceted. While the foot is the only interface of the human body in contact with the ground, function-al constructions for good control, ground support, grip ability and agility are suggested to improve sports performance [20]. Inappropriate shoes and shoe fitting can cause several foot problems [21], such as blisters, squeezed toes, and soft tissue bruises [20]. The function of badminton shoes is aimed at minimizing the injury risks [22] whilst maximizing sports performance and comfort. Typically, badminton movements are highly asymmetrical with clear functional differences between the dominant and non-dominant legs. Hence, the purpose of this study was to examine the gender differences in footwear demands and foot injuries in badminton using a supervised questionnaire method. The results from this study can help to understand and collate badminton footwear requirements and foot pain mechanisms to provide insights of footwear feature recommendations and footwear development. 


\section{Methods}

\subsection{Participants}

A total of 326 recreational badminton players completed the supervised questionnaire. All of the respondents were recruited from recreational competition events held in Beijing, China in October 2019. All respondents were above 18 years old and reported no previous lower limb surgery or neurological injury. Details of participant numbers are listed in Table 1. All respondents provided their informed consent and participated on a voluntary basis.

\subsection{Data collection}

The Supervised custom questionnaire was completed by participants under supervision of trained experimenters, who provided guidance and supervision to ensure the validity of the data. The questionnaire was categorized into four sections: (1) participant profile, (2) importance of shoe properties (3) shoe complaints. (4) pain or discomfort in different foot regions.

In section one, participant profiles regarding gender, age, height and weight were obtained. Section two and three required respondents to indicate subjects rating on the importance of shoe properties and shoe complaints, respectively. In section two, the importance of shoe properties was selected as the common shoe requirements during gameplays, which was established based on previous studies on footwear properties in running, basketball and gym training $[11,12,15,23]$. The assessed variables were overall evaluation of shoe, heel cushioning, forefoot cushioning, arch support, forefoot bending stiffness, traction/grip, durability, and stability. All respondents indicated their preferences on the 9-point Likert scale (1-extremely unimportant, 2-very unimportant, 3-unimportant, 4-somewhat unimportant, 5-neutral, 6somewhat important, 7-important, 8very important, 9extremely important).

In section three, the footwear complaint was defined as any footwear problems encountered in badminton, including poor breathability, blisters, loose shoelaces, poor insole grip, forefoot squeezing toes (media-lateral), forefoot squeezing toes (dorsal), forefoot upper too hard, forefoot sole too hard (plantar pain), forefoot sole too soft (instability/sprain ankle), heel cup too soft (instability/sprain ankle), insufficient arch support, and excessive arch support. All of the shoe properties and footwear complaints were extracted from previous studies on footwear comfort perception $[3,11,23,24]$ as well as advice from badminton coaches. All respondents gave their rating on the 9pointLikert scale (1-extremely comfortable, 2-very comfortable, 3-comfortable, 4-somewhat comfortable, 5-neutral, 6-somewhat uncomfortable, 7-uncomfortable, 8-very uncomfortable, 9-extremely uncomfortable). The Likert scale has a good reliability and validity to measure subjective perception $[25,26]$.

In section four, respondents were asked to indicate any pain or discomfort at 12foot regions (Fig. 1), including hallux, other four toes, first metatarsophalangeal (MTP), second-fifth MTP, cuneiform bone, cuboid bone, navicular bone, talus, heel, soft tissues of the foot, arch, and Achilles' tendon, as described 
in previous studies [27][28]. The degree of pain/discomfort was assessed by 3-point Likert scale (never pain, occasionally pain, and frequent pain) [29] for the dominant and non-dominant feet, respectively.

In addition, the subjective assessment was determined for respective dominant and non-dominant legs, as badminton is considered as a highly asymmetrical sport that results in uneven loading and movement characteristics. The more sensitive dominant side will be more suitable for athletes to used during competition, which may lead to the larger discrepancy of the strength and movement characteristics between dominant and non-dominant legs. Therefore, we also evaluated the requirements for footwear and pain on the dominant and the non-dominant sides [30].

\subsection{Data analysis}

The date obtained were showed as means and standard deviations, and as frequencies. The gender differences in all variables were analyzed using the Mann-Whitney $U$ test, and the differences between the dominant and non-dominant feet were analyzed using the Wilcoxon Signed Ranks Test. The significance level was set at $\mathrm{P}<0.05$. All statistical analyses were conducted using SPSS 21.0 (SPSS Inc., Chicago, IL, USA).

\section{Result}

\subsection{Importance of shoe properties}

In Table 2, both males and females rated shoe fit as the most important variable, followed by shoe comfort and injury protection. The Mann-Whitney $U$ test showed significant differences in the importance of some shoe features between males and females. Females reported higher importance of forefoot cushioning, comfort, breathability, color and upper durability than males $(P=0.002,0.032,0.043,0.049<$ 0.05).

Wilcoxon Signed Ranks Test was used to compare the importance of shoe characteristics between dominant and non-dominant sides, respectively (Table 3 ). For males, heel cushioning and heel stability were more important $(P=0.000,0.010)$ but the upper durability were less important on the dominant side $(P=0.002)$ compared with the non-dominant side. For females, forefoot cushioning on the dominant shoe was significantly more important than the non-dominant shoe $(P=0.019)$.

\subsection{Shoe problems/complaints}

Descriptive statistics showed that none of the shoe problems were extremely serious, but individual differences were large (Table 4). By ranking the severity of shoe problems, sole too hard (plantar pain) of non-dominant foot was considered as the most serious footwear problem by both males and females. For males, the next ranking was the soles on the dominant soles, the sole on the dominant heel was too hard, and the sole on the non-dominant heel was too hard. For females, the next shoe problem ranking was squeezing toes (medial-lateral), forefoot upper, and sole too hard on the dominant foot (Table 4). 
The Mann-Whitney $U$ test reported that the shoe problem of excessive arch support on both dominant and non-dominant sides was significantly higher in males than females ( $P=0.017,0.018$, Table 4). Wilcoxon Signed Ranks test showed no significant difference between dominant and non-dominant sides (Table 5).

\subsection{Pain or discomfort in different foot regions.}

The foot regions with occasional pain or frequent pain were distributed in the forefoot, followed by rearfoot and midfoot regions (Table 6). The gender difference results showed that occasional pain in the hallux on both dominant and non-dominant feet was more likely in females than males $(P=0.017,0.032)$. On the other hand, the heel frequent pain on the dominant and non-dominant sides of males were significantly higher than that of females $(P=0.009,0.023)$. Similarly, the soft tissue of the foot on the dominant side was significantly higher in males than females $(P=0.028)$.

\section{Discussion}

Badminton requires athletes to perform substantial explosive movements on joint loading [30][31], which could be related to various extremely rapid and intense activities during the game [32]. The foot is susceptible to considerable high level pressure, which increase the risks of potential foot injury [33]. Badminton shoes are clearly different from other sports shoes, and they must be functionally suitable for the characteristics of badminton players [4]. The basic requirements of badminton footwear usually focus on the soles, the weight and appearance [30], [34]. It is generally believed that the correct shoe shape is obtained by matching shoe shape to foot shape [35]. Therefore, appreciation of the gender differences in foot shape is essential to the proper design of both male and female footwear. [18]. However, it is still questionable if male and female athletes would demonstrate different footwear requirements, foot complaints and foot injury locations, since there are considerable anthropometrical and biomechanical differences between genders. The objective of this study was to investigate the shoe requirements, shoe problems/complaints and pain locations in males and females using supervised questionnaires. The results from this study can provide insights for badminton footwear development.

Our results showed that the fit and comfort of badminton shoes were recognized as the most important shoe feature in both males and females. This is similar to previous research on running, soccer, gym, basketball and tennis footwear, which also indicate fit and comfort as the most important shoe features $[1,11-14]$. Moreover, it has been shown that footwear comfort has significant influences on lower limb injuries and performances. In a prospective study involving 206 military personnel, the incidence of stress fractures and pain was found to be reduced in a more comfortable shoe condition [36]. In another research studing comfort during standing tasks, preferred footwear conditions were shown to result in the lowest levels of lower extremity and back pain [37]. In addition to affecting injuries, it has been suggested that footwear comfort is related to sport performances [37,38]. Some studies have found significant improvements in running economy during the most comfortable shoe conditions [39].

Shoe fit is a prerequisite to shoe comfort as well as sports performance, fatigue and injury prevention [14, $40,41]$. Comfortable fit is also considered essential for shoe performance.[42-44]. Fit and comfort are 
closely related to shoe design. [45] Although shoe fit and comfort were ranked as important by both genders, the higher importance of fit and comfort was found in female players. One possible explanation is that females may have different foot shape, with wider forefoot and narrower heel, compared with males [18, 19,46]. However, most female sports shoes are scaled down versions of male shoes [46], resulting in concerns on shoe fit. Another explanation is due to the higher hallux valgus angles found in females than males [47-52], which would result in more sensitivity to shoe upper pressures exerted on the hallux and therefore higher frequency of discomfort of the female hallux.

In our study, females reported importance for shoe color, dominant forefoot cushioning and upper durability than the males, suggesting that colour should be considered in female footwear. Biomechanically, the function of shoes is minimally affected by color. From the cognitive science perspective, colour can influence human cognition, perception and behaviour, which may further impact on motor performances [6,53,54][55]. The earliest study investigating the color of badminton shoes [56] indicated that badminton shoes should concentrate on exciting colors (e.g., red) and material combinations, which would help improve wearer's sports performance perception.

Compared to males, females have a wider pelvis width, which is associated with greater genu valgus, increased femoral anteversion, greater external tibial torsion and a greater Q-angle. Previous work has shown that female athletes have higher knee injury rates than male athletes in many court sports such as basketball and soccer [57], which is partly consistent with our survey results. Our female respondents rated shoe cushioning as one of the important shoe features in badminton and the need for shoe cushioning was more important in the dominant leg compared with the non-dominant leg to lower the impact of the lower limbs during exercise. Since females have narrower heel and higher medial arch than males [19], females prefer shoes with better upper fit and durability.

Based on our shoe problem/complaints findings, there were no gender differences found for the majority of shoe problems/complaints in regular sports. Due to the different anatomical structures of male and female feet, female arches are higher than males. Excessive arch support causes excessive ankle varus, which is suggested to increase the risk of ankle sprain [58][59]. Subjectively, athletes exhibit differences in perceived shoe stiffness based on mechanical properties. As a result, soft soles were more popular than hard soles, and shoes with a stiffer forefoot were considered particularly uncomfortable for recreational athletes, [60]. Our foot discomfort and pain results showed that the plantar region was the most susceptible to discomfort or pain regardless of gender. Together with the findings from the "importance of shoe properties" section, which showed a higher demand on fore-foot cushioning. Moreover, our recreational badminton athletes complained of hard forefoot soles. In the future, forefoot cushioning should be improved to minimize the risk potential of foot and lower limb injuries.

Several limitations need to be considered when interpreting our data. First, badminton athletes did not wear the same shoes, which may result in different wearing experiences and footwear preferences. Second, only recreational athletes and adult athletes were recruited for the study. Our results may not be generalizable to athletes at elite or lower playing levels. Highly skilled athletes demonstrated larger lunge 
distance and landing angles as well as higher movement intensities, implying that different shoe demands and foot pain/injury profiles.

\section{Conclusion}

This study provided comprehensive information related to badminton shoe demands, shoe problems/complaints, and discomfort locations in respective leg-dominance and genders. Good fit and comfort are considered as the most important shoe features for badminton shoes. The differences between dominant and non-dominant shoes were not obvious, while there were clear differences in shoe feature demand between females and males. These findings suggest that female-specific shoes are recommended for better shoe fit and comfort, as indicated by the anthropometrical differences between genders.

\section{Declarations}

\section{Ethics approval and consent to participate}

The study was approved by Ningbo University Ethics Committee. All participants provided informed, written consent.

\section{Consent for publication}

Not applicable

\section{Availability of data and materials}

The datasets used and/or analysed during the current study are available from the corresponding author on reasonable request.

\section{Competing interests}

The authors declare that they have no competing interests.

\section{Funding}

This research was funded by the National Social Science Fund of China (20BTY029); Science Foundation of the State Key Laboratory (Grant No. SMFA18B09).

\section{Authors' contributions}

WKL conceived the project and SS conducted data analysis and interpretation. JT \& SWJ collected the data. MD conducted all the statistical analysis. SS, WKL, JT, SWJ, JSB, UCU, F\& YG drafted the final manuscript. All authors read, corrected and approved the final manuscript. 
None.

\section{References}

1. Hoitz F, Mohr M, Asmussen M, Lam WK, Nigg S, Nigg B. The effects of systematically altered footwear features on biomechanics, injury, performance, and preference in runners of different skill level: a systematic review. Footwear Sci [Internet]. Taylor \& Francis; 2020;12:193-215. Available from: https://doi.org/10.1080/19424280.2020.1773936.

2. Lam WK, Kan WH, Chia JS, Kong PW. Effect of shoe modifications on biomechanical changes in basketball: A systematic review. Sport Biomech. Taylor \& Francis; 2019. pp. 1-27.

3. Honert EC, Mohr M, Lam W-K, Nigg S. Shoe feature recommendations for different running levels: A Delphi study. PLoS One. 15: Public Library of Science San Francisco, CA USA; 2020. p. e0236047.

4. Park S-K, Lam W-K, Yoon S, Lee K-K, Ryu J. Effects of forefoot bending stiffness of badminton shoes on agility, comfort perception and lower leg kinematics during typical badminton movements. Sport Biomech Taylor Francis. 2017;16:374-86.

5. Lam W-K, Ryue J, Lee K-K, Park S-K, Cheung JT-M, Ryu J. Does shoe heel design influence ground reaction forces and knee moments during maximum lunges in elite and intermediate badminton players? PLoS One. 12: Public Library of Science San Francisco, CA USA; 2017. p. e0174604.

6. Kam KKW, Uiga L, Lam W, Capio CM. M (2021) The colour we wear: Impact on self-predicted and actual motor performance. The Journal of Sport and Exercise Science, 5 ( 1 ). Downloaded from : https://e-space.mmu.ac.uk/627332/ Version: Published Version Publisher : Sport and Exercise Sci. $2021 ; 5$.

7. Garrick BJ. Examining the Realities of Risk Management. Springer US; 1987.

8. Feit EM, Berenter R. Lower extremity tennis injuries. Prevalence, etiology, and mechanism. J Am Podiatr Med Assoc. 1993;83:509.

9. Llana S, Brizuela G, Alcántara E, Martínez A, García AC. STUDY OF COMFORT ASSOCIATED WITH TENNIS FOOTWEAR. 1998.

10. Nigg BM, Baltich J, Hoerzer S, Enders $\mathrm{H}$. Running shoes and running injuries: mythbusting and a proposal for two new paradigms:'preferred movement path'and 'comfort filter.' Br J Sports Med. 49: BMJ Publishing Group Ltd and British Association of Sport and Exercise Medicine; 2015. pp. 12904.

11. Apps C, Liu H, Pykett J, Sterzing T. Gym training shoe requirements in China and England. Footwear Sci [Internet]. Taylor \& Francis; 2015;7:51-62. Available from:

http://dx.doi.org/10.1080/19424280.2014.983446.

12. Brauner $T$, Zwinzscher $M$, Sterzing $T$. Basketball footwear requirements are dependent on playing position. Footwear Sci. 2012;4:191-8. 
13. Althoff K, Hennig EM. Criteria for gender-specific soccer shoe development. Footwear Sci Taylor Francis. 2014;6:89-96.

14. Sterzing F, Brunner TB, Ernst I, Baus WW, Greve B, Herfarth K, et al. Stereotactic body radiotherapy for liver tumors. Strahlentherapie Onkol Springer. 2014;190:872-81.

15. Alcántara-Ayala I. Geomorphology, natural hazards, vulnerability and prevention of natural disasters in developing countries. Geomorphology Elsevier. 2002;47:107-24.

16. Mickle KJ, Steele JR, Munro BJ. Is the foot structure of preschool children moderated by gender? J Pediatr Orthop LWW. 2008;28:593-6.

17. Taş S, Korkusuz F, Erden Z. Neck muscle stiffness in participants with and without chronic neck pain: a shear-wave elastography study. J Manipulative Physiol Ther Elsevier. 2018;41:580-8.

18. Wunderlich RE, Cavanagh PR. Gender differences in adult foot shape: implications for shoe design. Med Sci Sports Exerc. 2001;33:605-11.

19. Krauss I, Grau S, Mauch M, Maiwald C, Horstmann T. Sex-related differences in foot shape. Ergonomics Taylor Francis. 2008;51:1693-709.

20. Park S, Stefanyhyn D, Worobets J, Lee J, Lee K, Park J. Biomechanical aspects of badminton shoe during a lunge. ISBS-Conference Proc Arch. 2009.

21. Høy K, Lindblad BE, Terkelsen CJ, Helleland HE. Badminton injuries-a prospective epidemiological and socioeconomic study. Br J Sports Med British Association of Sport Excercise Medicine. 1994;28:276-9.

22. Marchena-Rodriguez A, Gijon-Nogueron G, Cabello-Manrique D, Ortega-Avila AB. Incidence of injuries among amateur badminton players: A cross-sectional study. Medicine. 2020;99:e19785.

23. Lam WK, Sterzing T, Cheung JT-M. Reliability of a basketball specific testing protocol for footwear fit and comfort perception. Footwear Sci Taylor Francis. 2011;3:151-8.

24. Brauner $T$, Zwinzscher $M$, Sterzing T. Basketball footwear requirements are dependent on playing position. Footwear Sci Taylor Francis. 2012;4:191-8.

25. Matthias EC, Banwell HA, Arnold JB. Methods for assessing footwear comfort: a systematic review. Footwear Sci [Internet]. Taylor \& Francis; 2021;13:255-74. Available from: https://doi.org/10.1080/19424280.2021.1961879.

26. Isherwood J, Wang H, Sterzing T. Running biomechanics and running shoe perception of Chinese men and women. Footwear Sci [Internet]. Taylor \& Francis; 2021;13:55-67. Available from: https://doi.org/10.1080/19424280.2020.1853827.

27. Gefen A, Megido-Ravid M, Itzchak Y, Arcan M. Biomechanical analysis of the three-dimensional foot structure during gait: A basic tool for clinical applications. J Biomech Eng. 2000;122:630-9.

28. Chen WM, Lee SJ, Lee PVS. Plantar pressure relief under the metatarsal heads - Therapeutic insole design using three-dimensional finite element model of the foot. J Biomech [Internet]. Elsevier; 2015;48:659-65. Available from: http://dx.doi.org/10.1016/j.jbiomech.2014.12.043. 
29. Llana S, Brizuela G, Durá JV, García AC. A study of the discomfort associated with tennis shoes. J Sports Sci. 2002;20:671-9.

30. Nadzalan AM, Azmi SH, Mohamad NI, Lee JLF, Tan K, Chinnasee C. Kinematics analysis of dominant and non-dominant lower limb during step and jump forward lunge in badminton. J Fundam Appl Sci [Internet]. 2018;10:232-42. Available from: http://www.jfas.info.

31. Phomsoupha M, Laffaye $G$. The science of badminton: game characteristics, anthropometry, physiology, visual fitness and biomechanics. Sport Med Springer. 2015;45:473-95.

32. Bravo-Sánchez A, Abián-Vicén J, Jiménez F, Abián P. Influence of badminton practice on calcaneal bone stiffness and plantar pressure. Phys Sportsmed Taylor Francis. 2020;48:98-104.

33. Lam W-K, Wong DW-C, Lee WC-C. Biomechanics of lower limb in badminton lunge: a systematic scoping review. 8: PeerJ. PeerJ Inc.; 2020. p. e10300.

34. Lam WK, Kan WH, Chia JS, Kong PW. Effect of shoe modifications on biomechanical changes in basketball: A systematic review. Sport Biomech [Internet]. Routledge; 2019;00:1-27. Available from: https://doi.org/10.1080/14763141.2019.1656770.

35. Miller RG, Redwood SR. Manual of Shoemaking. C. \& J. Clark Ltd Print Dep; 1976.

36. Mundermann A, Stefanyshyn DJ, Nigg BM. Relationship between footwear comfort of shoe inserts and anthropometric and sensory factors. Med Sci Sports Exerc. WILLIAMS \& WILKINS; 2001;33:1939-45.

37. Nigg BM, Nurse MA, Stefanyshyn DJ. Shoe inserts and orthotics for sport and physical activities. Med Sci Sports Exerc. WILLIAMS \& WILKINS; 1999;31:S421-8.

38. Nigg BM. The role of impact forces and foot pronation: a new paradigm. Clin J Sport Med LWW. 2001;11:2-9.

39. Luo G, Stergiou P, Worobets J, Nigg B, Stefanyshyn D. Improved footwear comfort reduces oxygen consumption during running. Footwear Sci Taylor Francis. 2009;1:25-9.

40. Schubert C, Oriwol D, Sterzing T. Gender and age related requirements of running shoes: A questionnaire on 4501 runners. Footwear Sci. 2011;3.

41. Sterzing T, Müller C, Hennig EM, Milani TL. Actual and perceived running performance in soccer shoes: A series of eight studies. Footwear Sci Taylor Francis. 2009;1:5-17.

42. Frederick EC, Wojcieszak C. Textile use in sport shoes. Text Sport. Elsevier; 2005. pp. 339-51.

43. Au EYL, Goonetilleke RS. A qualitative study on the comfort and fit of ladies' dress shoes. Appl Ergon Elsevier. 2007;38:687-96.

44. Luximon A, Goonetilleke R, Tsui K. Foot landmarking for footwear customization. Ergonomics Taylor Francis. 2003;46:364-83.

45. Lam WK, Fung HT, Poolton JM. Footwear fit perception with or without attention. Footwear Sci Taylor Francis. 2015;7:181-90.

46. Frey C. Foot health and shoewear for women. Clin Orthop Relat Res LWW. 2000;372:32-44. 
47. JORDAN HH, BRODSKY AE. Keller operation for hallux valgus and hallux rigidus: an end result study. AMA Arch Surg American Medical Association. 1951;62:586-96.

48. Hardy RH, Clapham JCR. Observations on hallux valgus. J Bone Joint Surg Br. The British Editorial Society of Bone Joint Surgery. 1951;33:376-91.

49. Mann RA, Coughlin MJ. Hallux valgus--etiology, anatomy, treatment and surgical considerations. Clin Orthop Relat Res. 1981;31-41.

50. Piggott $\mathrm{H}$. The natural history of hallux valgus in adolescence and early adult life. J Bone Joint Surg $\mathrm{Br}$ The British Editorial Society of Bone Joint Surgery. 1960;42:749-60.

51. Schemitsch E, Horne G. Wilson's osteotomy for the treatment of hallux valgus. Clin Orthop Relat Res. 1989;221-5.

52. Coughlin MJ, Jones CP. Hallux valgus: Demographics, etiology, and radiographic assessment. Foot Ankle Int. 2007;28:759-77.

53. Elliot AJ, Maier MA, Moller AC, Friedman R, Meinhardt J. Color and psychological functioning: the effect of red on performance attainment. J Exp Psychol Gen American Psychological Association. 2007;136:154.

54. Feltman R, Elliot AJ. The influence of red on perceptions of relative dominance and threat in a competitive context. J Sport Exerc Psychol Human Kinetics Inc. 2011;33:308-14.

55. Sorokowski P, Sorokowska A, Witzel C. Sex differences in color preferences transcend extreme differences in culture and ecology. Psychon Bull Rev Springer. 2014;21:1195-201.

56. Liang Z, Li J. Progresses of the Badminton equipment relate to exercise: Some training aspects. Some Train Asp J Sport Med Ther. 2018;3:1-9.

57. Hootman JM, Dick R, Agel J. Epidemiology of collegiate injuries for 15 sports: summary and recommendations for injury prevention initiatives. J Athl Train National Athletic Trainers Association. 2007;42:311.

58. Kristianslund E, Bahr R, Krosshaug T. Kinematics and kinetics of an accidental lateral ankle sprain. J Biomech Elsevier. 2011;44:2576-8.

59. Xiong S, Goonetilleke RS, Witana CP, Weerasinghe TW, Au EYL. Foot arch characterization: A review, a new metric, and a comparison. J Am Podiatr Med Assoc. 2010;100:14-24.

60. Sterzing T, Schweiger V, Ding R, Cheung JTM, Brauner T. Influence of rearfoot and forefoot midsole hardness on biomechanical and perception variables during heel-toe running. Footwear Sci. 2013;5:71-9.

\section{Tables}

\section{Table1 Study population by genders.}




\begin{tabular}{|lll|}
\hline Study population & Male $(\mathrm{n}=200)$ & Female $(\mathrm{n}=126)$ \\
\hline Age $(\mathrm{yr})$. & $30.9 \pm 11.8$ & $33.18 \pm 12.1$ \\
\hline Weight $(\mathrm{kg})$ & $72.9 \pm 12.5$ & $57.97 \pm 9.5$ \\
\hline Height $(\mathrm{cm})$ & $175.0 \pm 16.8$ & $165.79 \pm 6.3$ \\
\hline BMl $(\mathrm{kg} / \mathrm{m} 2)$ & $23.3 \pm 3.4$ & $21.3 \pm 2.7$ \\
\hline
\end{tabular}

Table 2 Importance of shoe properties between genders

\begin{tabular}{|c|c|c|c|c|c|c|c|}
\hline \multirow{2}{*}{ Shoe function } & & & \multicolumn{2}{|l|}{ Male } & \multicolumn{2}{|l|}{ Female } & \multirow{2}{*}{$P$} \\
\hline & & & Mean $\pm S D$ & Rank & Mean $\pm S D$ & Rank & \\
\hline \multirow{7}{*}{ Overall } & Comfort & & $8.25 \pm 1.5$ & 2 & $8.66 \pm 0.86$ & 2 & $0.002^{*}$ \\
\hline & Breathability & & $7.37 \pm 1.89$ & 22 & $7.83 \pm 1.54$ & 14 & $0.032 *$ \\
\hline & Fit & & $8.38 \pm 1.48$ & 1 & $8.73 \pm 0.57$ & 1 & 0.103 \\
\hline & Injury protection & & $8.24 \pm 1.58$ & 3 & $8.55 \pm 0.88$ & 3 & 0.344 \\
\hline & Weight & & $7.10 \pm 1.87$ & 24 & $7.33 \pm 1.64$ & 24 & 0.412 \\
\hline & Color & & $5.57 \pm 2.55$ & 27 & $6.48 \pm 2.19$ & 27 & $0.002 *$ \\
\hline & $\begin{array}{l}\text { Performance } \\
\text { enhancement }\end{array}$ & & $7.7 \pm 1.82$ & 14 & $7.47 \pm 1.82$ & 23 & 0.172 \\
\hline \multirow[b]{2}{*}{ Cushioning-Fore } & & $\mathrm{D}$ & $7.79 \pm 1.61$ & 10 & $8.20 \pm 1.19$ & 5 & $0.043^{*}$ \\
\hline & & ND & $7.79 \pm 1.6$ & 11 & $7.96 \pm 1.46$ & 11 & 0.482 \\
\hline \multirow{2}{*}{ Cushioning-Heel } & & $\mathrm{D}$ & $7.98 \pm 1.55$ & 6 & $7.97 \pm 1.56$ & 10 & 0.928 \\
\hline & & ND & $7.62 \pm 1.71$ & 16 & $7.83 \pm 1.52$ & 15 & 0.312 \\
\hline \multirow{2}{*}{ Arch support, } & & $\mathrm{D}$ & $7.43 \pm 1.82$ & 19 & $7.55 \pm 1.64$ & 20 & 0.797 \\
\hline & & ND & $7.38 \pm 1.65$ & 20 & $7.52 \pm 1.65$ & 21 & 0.816 \\
\hline \multirow{2}{*}{$\begin{array}{l}\text { Forefoot } \\
\text { stiffness }\end{array}$} & & $\mathrm{D}$ & $7.37 \pm 1.70$ & 23 & $7.60 \pm 1.60$ & 19 & 0.242 \\
\hline & & ND & $7.38 \pm 1.65$ & 21 & $7.52 \pm 1.61$ & 22 & 0.431 \\
\hline \multirow[b]{2}{*}{ Traction/Grip-Fore } & & $\mathrm{D}$ & $8.11 \pm 1.44$ & 5 & $8.24 \pm 1.26$ & 4 & 0.497 \\
\hline & & ND & $8.16 \pm 1.37$ & 4 & $8.18 \pm 1.31$ & 6 & 0.964 \\
\hline \multirow{2}{*}{ Traction/Grip-Heel } & & $\mathrm{D}$ & $7.79 \pm 1.67$ & 12 & $7.86 \pm 1.41$ & 13 & 0.715 \\
\hline & & ND & $7.68 \pm 1.68$ & 15 & $7.83 \pm 1.45$ & 16 & 0.700 \\
\hline \multirow[b]{2}{*}{ Durability-Bottom } & & $\mathrm{D}$ & $7.48 \pm 1.80$ & 18 & $7.73 \pm 1.54$ & 18 & 0.303 \\
\hline & & ND & $7.57 \pm 1.72$ & 17 & $7.75 \pm 1.53$ & 17 & 0.474 \\
\hline \multirow{2}{*}{ Durability-Upper } & & $\mathrm{D}$ & $6.53 \pm 2.18$ & 26 & $7.02 \pm 1.92$ & 25 & $0.049^{*}$ \\
\hline & & ND & $6.69 \pm 2.25$ & 25 & $7.02 \pm 1.64$ & 26 & 0.326 \\
\hline \multirow[b]{2}{*}{ Stability-Fore } & & $\mathrm{D}$ & $7.93 \pm 1.58$ & 7 & $8.17 \pm 1.25$ & 7 & 0.403 \\
\hline & & ND & $7.89 \pm 1.60$ & 8 & $8.13 \pm 1.30$ & 8 & 0.374 \\
\hline \multirow{2}{*}{ Stability-Heel } & & $\mathrm{D}$ & $7.88 \pm 1.64$ & 9 & $7.98 \pm 1.43$ & 9 & 0.854 \\
\hline & sine & ND & $7.72 \pm 1.72$ & 13 & $7.93 \pm 1.42$ & 12 & 0.530 \\
\hline
\end{tabular}

$\mathrm{D}=$ dominant; $\mathrm{ND}=$ non-dominant. *Indicates a significant difference, $P<0.05$. Table 3. Importance of shoe properties between dominant and non-dominant sides. 


\begin{tabular}{|c|c|c|c|c|c|c|}
\hline \multirow{2}{*}{ Shoe function } & \multicolumn{2}{|c|}{ Male (Mean \pm SD) } & \multirow[t]{2}{*}{$p$} & \multicolumn{2}{|c|}{ Female $($ Mean \pm SD $)$} & \multirow[b]{2}{*}{$p$} \\
\hline & Dominant & Non-dominant & & Dominant & Non-dominant & \\
\hline Cushioning-Fore & $7.79 \pm 1.61$ & $7.79 \pm 1.6$ & 0.88 & $8.20 \pm 1.19$ & $7.96 \pm 1.46$ & $0.019 *$ \\
\hline Cushioning-heel & $7.98 \pm 1.55$ & $7.62 \pm 1.71$ & $\begin{array}{l}0.000 \\
*\end{array}$ & $7.97 \pm 1.56$ & $7.83 \pm 1.52$ & 0.102 \\
\hline Arch support & $7.43 \pm 1.82$ & $7.38 \pm 1.65$ & 0.753 & $7.55 \pm 1.64$ & $7.52 \pm 1.65$ & 0.543 \\
\hline $\begin{array}{l}\text { Forefoot bending } \\
\text { stiffness }\end{array}$ & $7.37 \pm 1.70$ & $7.38 \pm 1.65$ & 0.829 & $7.60 \pm 1.60$ & $7.52 \pm 1.61$ & 0.083 \\
\hline Traction/Grip-Fore & $8.11 \pm 1.44$ & $8.16 \pm 1.37$ & 0.55 & $8.24 \pm 1.26$ & $8.18 \pm 1.31$ & 0.440 \\
\hline Traction/Grip-Heel & $7.79 \pm 1.67$ & $7.68 \pm 1.68$ & 0.057 & $7.86 \pm 1.41$ & $7.83 \pm 1.45$ & 0.641 \\
\hline Durability-Bottom & $7.48 \pm 1.80$ & $7.57 \pm 1.72$ & 0.33 & $7.73 \pm 1.54$ & $7.75 \pm 1.53$ & 0.815 \\
\hline Durability-Upper & $6.53 \pm 2.18$ & $6.69 \pm 2.25$ & $\begin{array}{l}0.002 \\
*\end{array}$ & $7.02 \pm 1.92$ & $7.02 \pm 1.64$ & 0.904 \\
\hline Stability-Fore & $7.93 \pm 1.58$ & $7.89 \pm 1.60$ & 0.598 & $8.17 \pm 1.25$ & $8.13 \pm 1.30$ & 0.714 \\
\hline Stability-Heel & $7.88 \pm 1.64$ & $7.72 \pm 1.72$ & $\begin{array}{l}0.010 \\
*\end{array}$ & $7.98 \pm 1.43$ & $7.93 \pm 1.42$ & 0.265 \\
\hline
\end{tabular}

*Indicates a significant difference, $P<0.05$.

Table 4 Shoe problems/complaints between genders

\begin{tabular}{|c|c|c|c|c|c|c|c|}
\hline \multirow{2}{*}{\multicolumn{3}{|c|}{ Shoe problems/complaints }} & \multirow{3}{*}{$\begin{array}{l}\text { Male } \\
\text { Mean } \pm \text { SD } \\
4.75 \pm 2.69\end{array}$} & \multirow{3}{*}{$\frac{\text { Rank }}{5}$} & \multirow{3}{*}{$\begin{array}{l}\text { Female } \\
\text { Mean } \pm \text { SD } \\
4.50 \pm 2.72\end{array}$} & \multirow{3}{*}{$\begin{array}{l}\text { Rank } \\
11\end{array}$} & \multirow{3}{*}{$\begin{array}{l}P \\
0.444\end{array}$} \\
\hline & & & & & & & \\
\hline Poor breathability & & & & & & & \\
\hline \multirow{2}{*}{ Blisters } & $\mathrm{D}$ & & $4.26 \pm 2.92$ & 21 & $3.98 \pm 3.18$ & 23 & 0.275 \\
\hline & ND & & $4.45 \pm 2.98$ & 12 & $4.02 \pm 3.11$ & 22 & 0.158 \\
\hline \multirow{2}{*}{ Loose shoelaces } & D & & $4.37 \pm 2.81$ & 14 & $4.28 \pm 2.96$ & 14 & 0.694 \\
\hline & ND & & $4.45 \pm 2.81$ & 13 & $4.24 \pm 2.93$ & 15 & 0.520 \\
\hline \multirow{2}{*}{ Poor Insole grip } & D & & $4.56 \pm 3.00$ & 8 & $4.56 \pm 3.02$ & 7 & 0.945 \\
\hline & ND & & $4.47 \pm 2.97$ & 11 & $4.52 \pm 3.03$ & 9 & 0.832 \\
\hline \multirow{4}{*}{$\begin{array}{l}\text { Forefoot: Squeezing toes } \\
\text { (medial-lateral) } \\
\text { Forefoot: squeezing toes } \\
\text { (dorsal) }\end{array}$} & & $\mathrm{D}$ & $4.68 \pm 2.97$ & 6 & $4.68 \pm 3.10$ & 2 & 0.899 \\
\hline & & ND & $4.61 \pm 3.01$ & 7 & $4.63 \pm 3.09$ & 6 & 0.865 \\
\hline & & D & $4.11 \pm 2.93$ & 25 & $4.53 \pm 3.10$ & 8 & 0.288 \\
\hline & & ND & $4.18 \pm 2.92$ & 22 & $4.45 \pm 3.08$ & 13 & 0.521 \\
\hline \multirow{2}{*}{ Forefoot: Upper Too hard } & & $\mathrm{D}$ & $4.49 \pm 2.89$ & 10 & $4.67 \pm 3.12$ & 3 & 0.708 \\
\hline & & ND & $4.55 \pm 2.91$ & 9 & $4.66 \pm 3.08$ & 5 & 0.905 \\
\hline \multirow{2}{*}{$\begin{array}{l}\text { Forefoot: Sole too hard } \\
\text { (plantar pain) }\end{array}$} & & D & $4.92 \pm 2.98$ & 2 & $4.67 \pm 2.88$ & 4 & 0.373 \\
\hline & & ND & $4.95 \pm 3.00$ & 1 & $4.69 \pm 2.90$ & 1 & 0.366 \\
\hline \multirow{2}{*}{$\begin{array}{l}\text { Forefoot: Sole too soft } \\
\text { (instability/sprain ankle) }\end{array}$} & & $\mathrm{D}$ & $4.28 \pm 2.90$ & 19 & $4.10 \pm 3.01$ & 19 & 0.492 \\
\hline & & ND & $4.31 \pm 2.96$ & 15 & $4.07 \pm 2.96$ & 21 & 0.415 \\
\hline \multirow{2}{*}{$\begin{array}{l}\text { Heel cup too soft } \\
\text { (instability/sprain ankle) }\end{array}$} & & $\mathrm{D}$ & $4.31 \pm 2.85$ & 16 & $4.22 \pm 2.94$ & 16 & 0.659 \\
\hline & & ND & $4.28 \pm 2.86$ & 20 & $4.19 \pm 2.97$ & 17 & 0.603 \\
\hline \multirow{2}{*}{$\begin{array}{l}\text { Heel: Sole too hard } \\
\text { (plantar pain) }\end{array}$} & & D & $4.90 \pm 2.80$ & 3 & $4.52 \pm 3.05$ & 10 & 0.216 \\
\hline & & ND & $4.87 \pm 2.79$ & 4 & $4.46 \pm 3.03$ & 12 & 0.192 \\
\hline \multirow{2}{*}{$\begin{array}{l}\text { Sole too soft } \\
\text { (instability/sprain ankle) }\end{array}$} & & D & $4.17 \pm 2.87$ & 23 & $3.85 \pm 2.99$ & 24 & 0.231 \\
\hline & & ND & $4.15 \pm 2.88$ & 24 & $3.80 \pm 2.98$ & 25 & 0.177 \\
\hline \multirow{2}{*}{ Insufficient arch support } & & $\mathrm{D}$ & $4.31 \pm 2.75$ & 17 & $4.09 \pm 2.77$ & 20 & 0.459 \\
\hline & & ND & $4.29 \pm 2.65$ & 18 & $4.13 \pm 2.81$ & 18 & 0.552 \\
\hline \multirow{2}{*}{ Excessive arch support } & & $\mathrm{D}$ & $3.90 \pm 2.65$ & 26 & $3.29 \pm 2.70$ & 26 & $0.018^{*}$ \\
\hline & $-x$ & ND & $3.87 \pm 2.67$ & 27 & $3.29 \pm 2.67$ & 27 & $0.017^{*}$ \\
\hline
\end{tabular}

$D=$ dominant; $N D=$ non-dominant. *Indicates a significant difference, $P<0.05$. 
Table 5. Shoe problems/complaints between dominant and non-dominant sides.

\begin{tabular}{|c|c|c|c|c|c|c|}
\hline \multirow[b]{2}{*}{ Shoe problems/complaints } & \multicolumn{3}{|l|}{ Male } & \multicolumn{3}{|l|}{ Female } \\
\hline & Dominant & $\begin{array}{l}\text { Non- } \\
\text { dominant }\end{array}$ & $P$ & $\begin{array}{l}\text { Domina } \\
\text { nt }\end{array}$ & $\begin{array}{l}\text { Non- } \\
\text { dominant }\end{array}$ & $P$ \\
\hline Blisters & $4.26 \pm 2.92$ & $4.45 \pm 2.98$ & 0.089 & $3.98 \pm 3.18$ & $4.02 \pm 3.11$ & 0.940 \\
\hline shoelaces & & & 74 & 96 & .93 & .417 \\
\hline Poor Insole grip & $4.56 \pm 3.00$ & & 0.106 & $4.56 \pm 3.02$ & $4.52 \pm 3.03$ & 0.739 \\
\hline $\begin{array}{l}\text { Forefoot: squeezing } \\
\text { toes (medial-lateral) }\end{array}$ & $4.68 \pm 2.97$ & $4.61 \pm 3.01$ & 0.402 & $4.68 \pm 3.10$ & $4.63 \pm 3.09$ & 0.206 \\
\hline $\begin{array}{l}\text { Forefoot: squeezing } \\
\text { toes (dorsal) }\end{array}$ & $4.11 \pm 2.93$ & $4.18 \pm 2.92$ & 0.279 & $4.53 \pm 3.10$ & $4.45 \pm 3.08$ & 0.066 \\
\hline $\begin{array}{l}\text { Forefoot: Upper Too } \\
\text { hard }\end{array}$ & $4.49 \pm 2.89$ & $4.55 \pm 2.91$ & 0.901 & $4.67 \pm 3.12$ & $4.66 \pm 3.08$ & 0.556 \\
\hline $\begin{array}{l}\text { Forefoot: Sole too hard } \\
\text { sole tplantar pain }\end{array}$ & $4.92 \pm 2.98$ & $4.95 \pm 3.00$ & 0.321 & $4.67 \pm 2.88$ & $4.69 \pm 2.90$ & 0.496 \\
\hline $\begin{array}{l}\text { Forefoot: Sole too soft } \\
\text { (instability/ sprain) } \\
\text { ankle }\end{array}$ & $4.28 \pm 2.90$ & $4.31 \pm 2.96$ & 0.694 & $4.10 \pm 3.01$ & $4.07 \pm 2.96$ & 0.832 \\
\hline $\begin{array}{l}\text { Heel cup too soft } \\
\text { (instability/sprain) } \\
\text { ankle }\end{array}$ & $4.31 \pm 2.85$ & $4.28 \pm 2.86$ & 0.820 & $4.22 \pm 2.94$ & $4.19 \pm 2.97$ & 0.357 \\
\hline $\begin{array}{l}\text { Heel: sole too hard } \\
\text { (plantar pain) }\end{array}$ & $4.90 \pm 2.80$ & $4.87 \pm 2.79$ & 0.391 & $4.52 \pm 3.05$ & $4.46 \pm 3.03$ & 0.07 \\
\hline $\begin{array}{l}\text { Heel: sole too soft } \\
\text { (instability/sprain) } \\
\text { ankle }\end{array}$ & $4.17 \pm 2.87$ & $4.15 \pm 2.88$ & 0.623 & $3.85 \pm 2.99$ & $3.80 \pm 2.98$ & 0.052 \\
\hline $\begin{array}{l}\text { Insufficient arch } \\
\text { support }\end{array}$ & $4.31 \pm 2.75$ & $4.29 \pm 2.65$ & 0.812 & $4.09 \pm 2.77$ & $4.13 \pm 2.81$ & 0.163 \\
\hline Excessive arch support & $3.90 \pm 2.65$ & $3.87 \pm 2.67$ & 0.383 & $3.29 \pm 2.70$ & $3.25 \pm 2.67$ & 0.336 \\
\hline
\end{tabular}


Table 6

Foot pain/ discomfort locations between genders.

\begin{tabular}{|c|c|c|c|c|c|c|c|c|}
\hline \multirow[t]{2}{*}{ Foot regions } & & \multicolumn{2}{|c|}{ NP (\%) } & \multicolumn{2}{|c|}{ OP (\%) } & \multicolumn{2}{|c|}{ FP (\%) } & \multirow{2}{*}{$\begin{array}{l}P \text {-values } \\
\text { Male vs. female }\end{array}$} \\
\hline & & male & female & male & female & male & female & \\
\hline \multirow[t]{2}{*}{ Hallux } & $\mathrm{D}$ & 87.5 & 77 & 10 & 21.4 & 2.5 & 1.6 & $0.017^{\star}$ \\
\hline & ND & 89 & 80.2 & 8 & 16.7 & 3 & 3.2 & $0.032^{\star}$ \\
\hline \multirow[t]{2}{*}{ Other toes } & $\mathrm{D}$ & 93 & 87.3 & 6 & 11.9 & 1 & 0.8 & 0.088 \\
\hline & ND & 94 & 93.7 & 4.5 & 6.3 & 1.5 & 0 & 0.926 \\
\hline \multirow[t]{2}{*}{ 1st MTP } & $\mathrm{D}$ & 76.5 & 76.2 & 21 & 20.6 & 2.5 & 3.2 & 0.747 \\
\hline & ND & 74.5 & 78.6 & 22.5 & 19 & 3 & 2.4 & 0.669 \\
\hline \multirow[t]{2}{*}{ 2nd -5th MTP } & $\mathrm{D}$ & 84.5 & 81.7 & 14 & 15.1 & 1.5 & 3.2 & 0.484 \\
\hline & ND & 89 & 87.3 & 10.5 & 11.9 & 0.5 & 0.8 & 0.638 \\
\hline \multirow[t]{2}{*}{ Cuneiform bone } & $\mathrm{D}$ & 97.5 & 95.2 & 2.5 & 2.4 & 0 & 2.4 & 0.259 \\
\hline & ND & 96 & 95.2 & 2.5 & 4.8 & 0.5 & 0 & 0.418 \\
\hline \multirow[t]{2}{*}{ Navicular bone } & $\mathrm{D}$ & 98.5 & 99.2 & 1.5 & 0 & 0 & 0.8 & 0.58 \\
\hline & ND & 99.5 & 97.6 & 0.5 & 2.4 & 0 & 0 & 0.569 \\
\hline \multirow[t]{2}{*}{ Talus } & $\mathrm{D}$ & 95.5 & 90.5 & 4.5 & 8.7 & 0 & 0.8 & 0.07 \\
\hline & ND & 96.5 & 97.6 & 3.5 & 2.4 & 0 & 0 & 0.95 \\
\hline \multirow[t]{2}{*}{ Cuboid bone } & $\mathrm{D}$ & 100 & 99.2 & 0 & 0.8 & 0 & 0 & 0.208 \\
\hline & ND & 97.5 & 97.6 & 2 & 1.6 & 0.5 & 0.8 & 0.950 \\
\hline \multirow[t]{2}{*}{ Heel } & $\mathrm{D}$ & 70.5 & 84.1 & 23 & 9.5 & 6.5 & 6.3 & $0.009 *$ \\
\hline & ND & 77.5 & 88.1 & 16.5 & 6.3 & 6 & 5.6 & $0.023^{*}$ \\
\hline \multirow[t]{2}{*}{ Soft tissues } & $\mathrm{D}$ & 93 & 98.4 & 6.5 & 1.6 & 0.5 & 0 & $0.028^{*}$ \\
\hline & ND & 95 & 96.8 & 4.5 & 2.4 & 0.5 & 0.8 & 0.435 \\
\hline \multirow[t]{2}{*}{ Arch } & $\mathrm{D}$ & 96.5 & 96 & 3.5 & 2.4 & 0 & 1.6 & 0.807 \\
\hline & ND & 96 & 95.2 & 3 & 4 & 1 & 0.8 & 0.747 \\
\hline \multirow[t]{2}{*}{ Achilles' tendon } & $\mathrm{D}$ & 99 & 94.8 & 1 & 1.6 & 0 & 0 & 0.640 \\
\hline & ND & 99.5 & 100 & 0.5 & 0 & 0 & 0 & 0.427 \\
\hline
\end{tabular}


Figures

Left foot
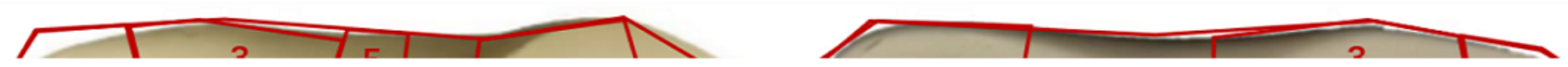

Figure 1

Diagram of the foot regions (Left foot).

1-Hallux, 2-Other four toes, 3-First MTP, 4-2nd-5th MTP, 5-cuneiform bone, 6-navicular bone, 7-Talus, 8Cuboid bone, 9-Heel, 10-Soft tissues of the foot, 11-Arch, 12-Achilles' tendon. 